\title{
Differential Responses of Antioxidative System to Soil Water Shortage in Barley (Hordeum vulgare L.) Genotypes
}

\author{
Irada Mammad Huseynova ${ }^{1 *}$, Masma Yagubali Nasrullayeva², \\ Samira Mahammadrahim Rustamova1, Durna Rafail Aliyeva1, Jalal Alirza Aliyev1 \\ ${ }^{1}$ Institute of Botany, Azerbaijan National Academy of Sciences, Baku, Azerbaijan \\ ${ }^{2}$ Institute of Genetic Resourses, Azerbaijan National Academy of Sciences, Baku, \\ Azerbaijan \\ Email: " huseynova-i@botany-az.org
}

Received 26 July 2014; revised 12 September 2014; accepted 27 September 2014

Copyright (C) 2014 by authors and Scientific Research Publishing Inc.

This work is licensed under the Creative Commons Attribution International License (CC BY).

http://creativecommons.org/licenses/by/4.0/

(c) (i) Open Access

\begin{abstract}
Drought is one of the major factors limiting the yield and quality of crops in the world. The activity of antioxidative system to tolerate the drought stress is significant in plants. In the present study, the activities and isoform profiles of catalase (CAT), ascorbate peroxidase (APX), glutathione reductase (GR), and superoxide dismutase (SOD) were analyzed in four barley genotypes grown under soil water restriction. Drought stress caused increase in the activities of CAT and SOD in all studied genotypes, while APX activity decreased. The total GR activity increased substantially in genotypes K 2778 and St.Garabag 7 and decreased in No. 77 local and St.Pallidum 596 genotypes under conditions of severe water stress. No detectable differences were observed in the isoenzyme pattern (the appearance of a new isoenzymes and disappearance of another one) between control plants and those subjected to soil drought. However, intensification of corresponding isoforms in electrophoretic spectra was observed in stressed barley leaves relative to watered ones. The obtained results possibly suggest that antioxidant protection in barley plants under drought conditions could be attributed mainly to SOD and CAT.
\end{abstract}

\section{Keywords}

Hordeum vulgare L., Drought, Reactive Oxygen Species, Antioxidant Enzymes

\footnotetext{
${ }^{*}$ Corresponding author.
}

How to cite this paper: Huseynova, I.M., Nasrullayeva, M.Y., Rustamova, S.M., Aliyeva, D.R. and Aliyev, J.A. (2014) Differential Responses of Antioxidative System to Soil Water Shortage in Barley (Hordeum vulgare L.) Genotypes. Advances in Biological Chemistry, 4, 351-359. http://dx.doi.org/10.4236/abc.2014.46040 


\section{Introduction}

Barley, in comparison with other cereal crops, has a better fodder value including both grain and straw. The major environmental factor that constrains the productivity and stability of crop plants is water stress [1] [2]. According to the different scenarios predicted by the Intergovernmental Panel on Climate Change [3] it is expected that there will be a reduction in precipitation and rising evapotranspiration rates.

When plants are exposed to environmental stresses such as drought, reactive oxygen species (ROS) such as superoxide $\left(\mathrm{O}_{2} \bullet\right)$, hydrogen peroxide $\left(\mathrm{H}_{2} \mathrm{O}_{2}\right)$, hydroxyl radicals $(\mathrm{OH} \bullet)$ and singlet oxygen $\left({ }^{1} \mathrm{O}_{2}\right)$ are produced [4]. The balance between the production of ROS and the quenching activity of the antioxidants is disturbed and this often results in oxidative damage. ROS are highly reactive to membrane lipids, protein and DNA [5]. Plants have developed efficient antioxidant system that can protect plants from this disaster [6]. The toxic effects of ROS are counteracted by enzymatic as well as non-enzymatic antioxidative system such as: superoxide dismutase (SOD), catalase (CAT), ascorbate peroxidase (APX), glutathione reductase (GR), ascorbic acid (AsA), tocopherol, glutathione and phenolic compounds, etc. Normally, each cellular compartment contains more than one enzymatic activity that detoxifies a particular ROS. Presence of these enzymes in almost all cellular compartments clears their crucial role of ROS detoxification for the survival of the plant [7] [8]. During the past few years, considerable progress has been made in understanding how plants protect themselves against oxidative stresses. In plants, over 150 genes encode for different ROS-detoxifying or ROS-producing enzymes forming well organized ROS gene web [9]. Several genes encoding for plant antioxidant enzymes have been cloned, characterized, and used in the construction of transgenic lines [10]. Genetic analysis of the paraquat-tolerant Conyza bonariensis indicated that all the three enzymes of HalliwelI-Asada pathway, i.e. SOD, APX and CAT, co-segregate [11]. Manipulation of genes that protect and maintain cellular functions or those maintain structure of cellular components has been the major target of attempts to produce plants that have enhanced stress tolerance.

Analysis of numerous literature data on this topic suggests that the common response to stress does not exist [4] [12]-[14]. The response of the antioxidant system to the stress effect of the same type depends on the plant species since the reaction of antioxidant system in leaves of various plants differs at the same level of drought. Activities of cytosolic ascorbate peroxidase and MDA-reductase decreased, whereas SOD and CAT activities remained unchanged in sorghum. In contrast, activities of chloroplastic peroxidase and catalase increased in sunflower [15]. Besides, the response of the antioxidant system is characterized by the degree and duration of stress. For example, in the two grass species activities of SOD, CAT and POD increased under soil drought, but when stress intensified, under severe stress the enzyme activities decreased, which correlated with the chlorophyll loss and destruction of membranes [16]. The reaction of the antioxidant system to stress probably depends on the initial level of antioxidant activity, which in turn is determined by the physiological state of the plant [17]. The activity of the antioxidant system could also be stipulated by the plant age and cultivation conditions [18].

Considering the above-mentioned, the aim of this work was to study the antioxidant enzymes, including catalase, ascorbate peroxidase, glutathione reductase and superoxide dismutase in barley genotypes grown under soil water deficit.

\section{Materials and Methods}

\subsection{Plant Materials}

St.Garabag 7 and No. 77 local species of Nutans specific diversity and St.Pallidum 596 and K-2778 genotypes of Palladium specific diversity were chosen as the investigation objects. The plants were cultivated at the Jalilabad Regional Experimental Station of the Azerbaijan Research Institute of Crop Husbandry under normal and drought conditions.

\subsection{Enzyme Extraction and Activity Determination}

Enzyme extract was prepared by homogenizing leaf material ( $1 \mathrm{~g} \mathrm{fr}$ wt) with a pestle in an ice-cold mortar with $0.05 \mathrm{M} \mathrm{Na}_{2} \mathrm{HPO}_{4} / \mathrm{NaH}_{2} \mathrm{PO}_{4}$ buffer ( $\mathrm{pH}$ 7.0). The homogenates were filtered through four layers of cheesecloth and then centrifuged at $4^{\circ} \mathrm{C}$. The supernatant were collected and used for the assays of enzymatic activities.

\subsection{CAT}

The activity of catalase was determined as a decrease in absorbance at $240 \mathrm{~nm}$ for $1 \mathrm{~min}$ following the decom- 
position of $\mathrm{H}_{2} \mathrm{O}_{2}$ as described by Kumar and Knowles [19]. The reaction mixture contained $50 \mathrm{mM}$ phosphate buffer ( $\mathrm{pH}$ 7.0) and $15 \mathrm{mM} \mathrm{H}_{2} \mathrm{O}_{2}$. The reaction was initiated by adding the enzyme extract. CAT activity $\left(\mu \mathrm{mol} \cdot \mathrm{min}^{-1} \cdot \mathrm{mg}^{-1} \cdot\right.$ protein) was defined using molecular extinction coefficient $\varepsilon=39.4 \mathrm{mM}^{-1} \cdot \mathrm{sm}^{-1}$.

\subsection{APX}

The activity of ascorbate peroxidase was assayed according to Nakano and Asada [20]. The assay mixture consisted of $0.05 \mathrm{mM}$ ASA, $0.1 \mathrm{mM} \mathrm{H}_{2} \mathrm{O}_{2}, 0.1 \mathrm{mM}$ EDTA, $50 \mathrm{mM}$ sodium phosphate buffer (pH 7.6), and $0.3 \mathrm{~mL}$ enzyme extract. The activity was measured as a decrease in absorbance at $290 \mathrm{~nm}$ for $30 \mathrm{sec}$. APX activity $\left(\mu \mathrm{mol} \cdot \mathrm{min}^{-1} \cdot \mathrm{mg}^{-1} \cdot\right.$ protein) was defined using molecular extinction coefficient $\varepsilon=2.8 \mathrm{mM}^{-1} \cdot \mathrm{sm}^{-1}$.

\subsection{GR}

Glutathione reductase activity was determined at $340 \mathrm{~nm}$ for $10 \mathrm{~min}$ in reaction mixture containing $100 \mathrm{mM}$ potassium phosphate buffer (pH 7.8), $1 \mathrm{mM}$ EDTA, $0.2 \mathrm{mM}$ NADPH and $0.5 \mathrm{mM}$ GSSG [21]. GR activity $\left(\mu \mathrm{mol} \cdot \mathrm{min}^{-1} \cdot \mathrm{mg}^{-1} \cdot\right.$ protein) was defined using molecular extinction coefficient $\varepsilon=6.2 \mathrm{mM}^{-1} \cdot \mathrm{sm}^{-1}$.

\subsection{SOD}

Superoxide dismutase activity was estimated by using SOD Assay Kit-WST (Sigma-Aldrich, USA). The absorbance was recorded at $450 \mathrm{~nm}$ and one enzyme unit of SOD activity was defined as the amount of the enzyme required to cause $50 \%$ inhibition of the rate of NBT reduction.

Protein content was determined according to Sedmak [22] by using bovine serum albumin as a standard.

\subsection{Determination of the Isoenzyme Composition of Enzymes}

Qualitative changes of the enzyme activity were investigated with native polyacrylamide gel (PAGE) using the Laemmli method [23] of gel electrophoresis with some modifications. The protein amount was determined by the method of Sedmak [22]. Bovine serum albumin was used for the construction of standard curve. An equal amount of the enzyme extract was mixed with bromophenol blue and glycerol to a final concentration of $12.5 \%$ $(\mathrm{v} / \mathrm{v})$. To determine the isoform composition of enzymes the method of electrophoresis in $10 \%$ (for APX) and $7 \%$ (for CAT) polyacrylamide gel under non-denaturating conditions in Tris- $\mathrm{HCl}$ buffer $(\mathrm{pH} 8.3), 4^{\circ} \mathrm{C}, 3 \mathrm{~h}$ supply of constant current of $30 \mathrm{~mA}$ was used. $2 \mathrm{mM}$ sodium ascorbate was added to the electrode buffer to detect APX activity. Visualization of APX isoforms was conducted according to Mittler and Zilinskas [24]. For visualization of ascorbate peroxidase, the gel was incubated in a solution containing $50 \mathrm{mM}$ potassium phosphate buffer ( $\mathrm{pH} 7.0$ ) and $2 \mathrm{mM}$ ascorbate-Na, for $30 \mathrm{~min}$. Then the gel was incubated in a solution containing $50 \mathrm{mM}$ potassium phosphate buffer (pH 7.0), $4 \mathrm{mM}$ sodium ascorbate and $2 \mathrm{mM} \mathrm{H}_{2} \mathrm{O}_{2}$, for 20 min and stained in a solution containing $50 \mathrm{mM}$ potassium phosphate buffer (pH 7.8), $28 \mathrm{mM}$ TEMED and $2.45 \mathrm{mM}$ nitro blue tetrazolium, for 15 min by mixing on a shaker. The gel was washed with distilled water to remove excess stain and was photographed. Catalase was stained on the gel by incubation in the dark for $20 \mathrm{~min}$ in the substrate (3.27 $\mathrm{mM} \mathrm{H}_{2} \mathrm{O}_{2}$ ) and developing (1\% potassium ferrocyanide and $1 \%$ ferric chloride) solutions [25].

\section{Results and Discussion}

Significant variations for antioxidant activity were found out among genotypes grown under normal water supply and drought stress. One of the antioxidant enzymes playing the main role in the plant protection system against oxidative stress is catalase. This enzyme provides a rapid utilisation of hydrogen peroxide [26]. Thus, catalase activity was assayed under normal and stress conditions in St.Garabag-7 and No. 77 local species of Nutans specific diversity and St.Pallidum-596 and K-2778 genotypes of Palladium specific diversity (Figure 1). Significant differences were not observed for catalase activity in normally watered plants. Catalase activity was higher in St.Garabag-7 (140 \pm 12 unit/mg protein) and lower in St.Pallidum 596 (90 $\pm 10 \mathrm{unit} / \mathrm{mg}$ protein) relative to other genotypes. In No. 77 local and K-2778 genotypes catalase activity was almost the same under normal conditions.

CAT activity increased in all genotypes subjected to drought stress. CAT activity in St.Garabag-7 genotype was found to be $260 \pm 24$ unit/mg protein, indicating 2-fold increase in the enzyme activity under drought compared with the normal conditions. Similar to normal conditions increases in catalase activity under stress 


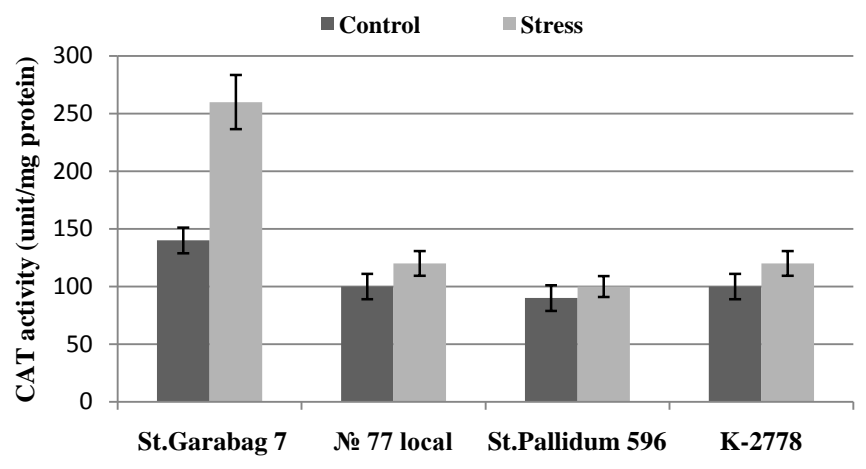

Figure 1. CAT activity of barley leaves under soil water shortage.

were almost the same (1.2 times) for No. 77 local and K-2778 genotypes. Water deficiency caused relatively small increase in CAT activity in St.Pallidum 596 (approx. 1.1 times), which reached $100 \pm 12$ unit/mg protein. The high activity of catalase under drought shows its protective role against stress.

Catalase is a chromoproteid thet contains oxidized heme as a prosthetic group (non-protein). Certain concentrations of hydrogen peroxide formed during exchange reactions have toxic effects on cells. Catalase neutralizes hydrogen peroxide, converting it into water and inactive molecular oxygen [7].

Another enzyme neutralizing hydrogen peroxide in living cells is peroxidase. However, it has been proven that catalase fulfills its catalytic function independently of peroxidase. Unlike peroxidases functioning at low peroxide levels, catalase can also act effectively at high concentrations of peroxides.

Ascorbate peroxidase can also plays an important role in plant protection against oxidative stress [27] [28]. APX is a key enzyme in the utilization of hydrogen peroxide in chloroplasts and cytosol of plant cells. The activity of hydrogen peroxide in barley genotypes has been analysed under normal and drought conditions (Figure 2). Among studied genotypes St.Garabag-7 was characterized by the maximum catalase and minimum ascorbate peroxidase activity (280 \pm 22 unit/mg protein) under normal conditions. Despite belonging to different specific diversities ascorbate peroxidase activity was almost the same in No. 77 (640 $\pm 52 \mathrm{unit} / \mathrm{mg}$ protein) local and K-2778 (640 \pm 66 unit/mg protein) genotypes of barley. It is interesting that catalase activity was also the same in these genotypes. Maximum activity of ascorbate peroxidase $(660 \pm 56 \mathrm{mMol} / \mathrm{mg} \mathrm{min})$ and minimum activity of CAT were detected in St.Pallidum 596 genotype of barley under normal conditions.

Figure 2 shows the influence of drought on ascorbate peroxidase activity. As seen in the figure contrary to catalase, ascorbate peroxidase activity decreased in all the genotypes under water deficiency. The minimum activity of the enzyme was observed in St.Garabag 7 (240 $\pm 21 \mathrm{unit} / \mathrm{mg}$ protein), and maximum activity in K-2778 genotype (360 \pm 33 unit/mg protein). In genotype St.Garabag 7 water deficiency led to slight decrease in ascorbate peroxidase activity compared with the control plants. Whereas in genotype K-2778, characterized by the maximum activity of ascorbate peroxidase under water deficiency, it decreased approximately twice compared with the control plants. Ascorbate peroxidase activity was the same in barley genotypes No. 77 and St.Pallidum 596 under stress showing 2.2- and 2.3-fold decreases in activity, respectively.

APX catalyses oxidation of ascorbate leading to the formation of monodehydroascorbate (MDA) radical. According to the intracellular compartmentation APX is divided into four types: APX dissolved in the chloroplast stroma (sAPX), APX connected to thylakoid (tAPX), cytosolic form (cAPX) and glyoxisome membrane form (gmAPX). Different authors indicated changes in APX activity under drought and heat stress [29]. Hydrogen peroxide is also known to induce the gene of APX cytosolic function and participate in signaling under oxidative stress [30].

Glutathione reductase is considered as an important enzyme in the protection of the plant antioxidant system. It catalyses the reduction of glutathione, oxidised in the presence of $\mathrm{NADPH}^{+}$in the glutathione ascorbate cycle [31]. Glutathione reductase activity was also determined (Figure 3). Among normal watered plants maximum and minimum activities of GR were observed in No. 77 local (99 \pm 10 unit/mg protein) and K-2778 (42 \pm 6 unit/mg protein) genotypes, respectively. Genotypes St.Garabag 7 and St.Pallidum 596 occupy intermediate positions for this parameter.

Figure 3 shows changes in glutathione reductase activities in various barley genotypes under water deficiency. Maximum and minimum activities of GR were observed for St.Garabag 7 (156 \pm 13 unit/mg protein) and 


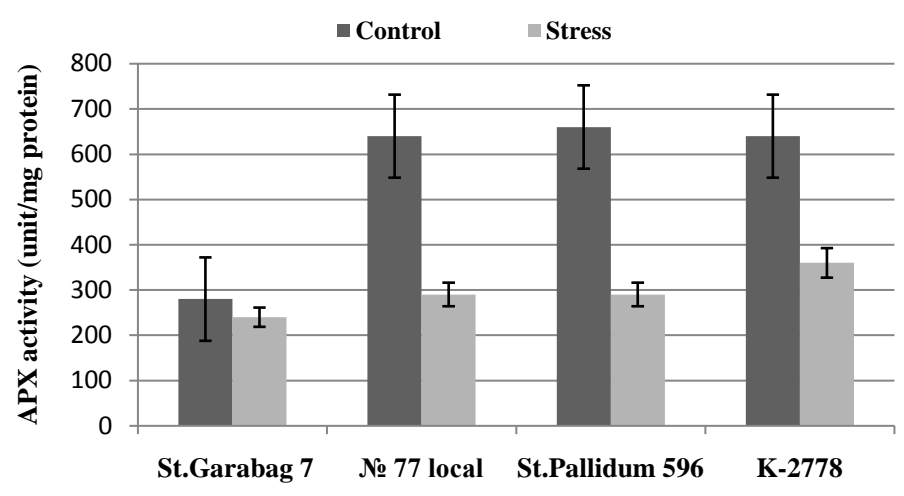

Figure 2. APX activity of barley leaves under soil water shortage.

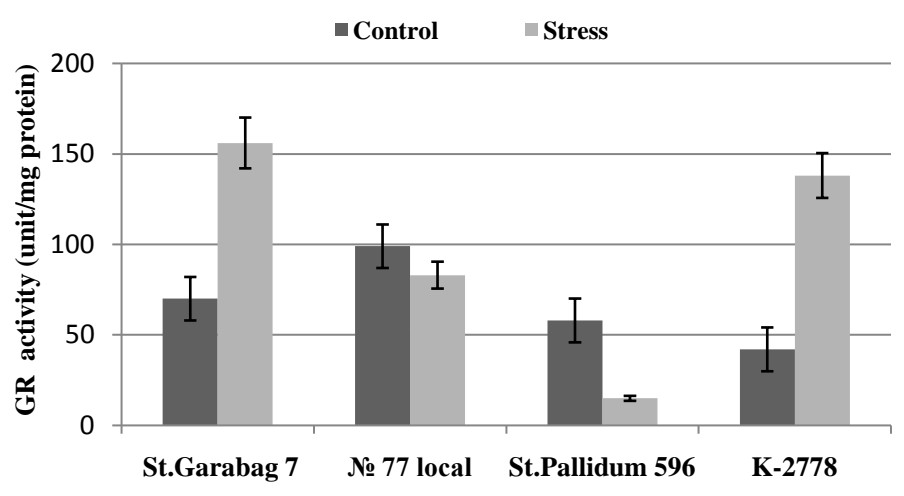

Figure 3. GR activity of barley leaves under soil water shortage.

St.Pallidum 596 (15 \pm 2 unit/mg protein), respectively. Genotypes K-2778 and No. 77 occupy intermediate positions for this parameter. It is noteworthy that the same tendency exists for CAT activity in this genotypes. Comparison of the stress and control variants showed that the highest increase (more than 3 times) in GR activity occured in genotype K-2778 under drought. Enzyme activity in stressed genotype St.Garabag 7 increased almost 2 times, decreased 0.2 times in genotype No. 774 times in genotype St.Pallidum 596.

Four isoforms of GR associated with different cell compartments exist in plants. The most amount of this enzyme is associated with chloroplasts. However, its isoenzymes were also detected in cytosol and mitichondria [31] [32]. Hydrogen peroxide formed by the reduction of the superoxide radical is released in cytoplasma, chloroplasts and membranes with participation of ascorbate peroxidase and oxidation of ascorbate occurs: $2 \mathrm{H}_{2} \mathrm{O}_{2}+$ ascorbate $\rightarrow$ dehydroascorbate $+\mathrm{H}_{2} \mathrm{O}+\mathrm{O}_{2}$. Dehydroascorbate forms ascorbate in the presence of reduced glutathione (GSH): 2GSH + dehydroascorbate $\rightarrow$ GSSG + ascorbate. Oxidised glutathione (GSSG) in turn is regenerated forming the reduced glutathione in the presence of $\mathrm{NADPH}\left(\mathrm{H}^{+}\right): \mathrm{GSSG}+\mathrm{NADPH}+\mathrm{H}+\rightarrow$ $2 \mathrm{GSH}+\mathrm{NADP}$.

Superoxide dismutase (SOD) catalyzes dismutase reaction of the superoxide radical $\mathrm{O}_{2} \cdot{ }^{-}$with the formation of molecular oxygen and hydrogen peroxide. SOD is one of the most important enzymes in the protection system of plants against stress and occurs in every cell of all plants [6] [33].

Figure 4 shows the effect of water deficiency on superoxide dismutase activity in different barley genotypes. The same maximum activity of superoxide dismutase was observed in genotypes No. 77 local and K-2778 under normal conditions. While minimum activity of the enzyme was observed for genotype St.Pallidum 596 (82 \pm 9 unit/mg protein).

As seen in Figure 4 superoxide dismutase activity increased in all studied barley genotypes under water deficiency. Maximum and minimum values for SOD activity were observed in genotypes St.Garabag 7 (100 \pm 13 unit/mg protein) and St.Pallidum 596 (93 \pm 8 unit/mg protein), respectively. It is interesting that the same tendency was observed for glutathione reductase activity under stress. Genotypes No. 77 local and K-2778 occupy intermediate positions. It should be noted that the comparison of stressed and control variants showed different patterns of activity changes. Thus, the highest increase in superoxide dismutase activity ( 1.2 times) 
was observed in St.Garabag 7 genotype under stress.

Some authors emphasized an important role of SOD in the antioxidant protection system under the influence of different stressors [33] [34]. But there are various isoforms of SOD reacting differently to water deficiency. Activities of MnSOD and FeSOD increased rapidly in response to water deficiency, while Cu/ZnSOD activity remained unchanged in cowpea plants [35]. SOD is known to be a multimer metalloprotein which has different isoforms characterized by the metal type, localized in the emzyme active center. According to the literature data the most common isoforms of SOD are those contained copper-zinc (Cu/ZnSOD), manganese (MnSOD), iron (FeSOD) and nickel (NiSOD) in the active center [4]. Induction of SOD in plant cells against different stress factors indicates its important role in the plant protection system. In general, SOD activity increases under water deficiency for the utilization of superoxide radicals. Under the influence of salinity and other adverse environmental factors different mechanisms are known to function against oxidative stress. In addition to the formation of a substrate for SOD, oxygen oxidation triggers different mechanisms.

Thus, the analysis of the main enzymes of the antioxidant protection system in four barley genotypes under normal and drought conditions showed that drought caused increases in catalase and SOD activities and a decrease in ascorbate peroxidase activity in all the studied genotypes. The activity of glutahtione reductase increased in genotypes St.Garabag 7 vo K-2778 and decreased in genotypes No. 77 local and St.Pallidum in response to drought.

Electrophoretic spectra of antioxidant enzymes from barley plants exposed to soil drought were also studied (Figure 5). Marked qualitative changes (appearance or disappearance of additional lines on electrophoregram were not revealed in the enzyme electrophoretic spectra. However, the intensification of the colors of the respective isoforms from barley leaves exposed to drought was detected in the electrophoretic spectra (Figure 5 and Figure 6).

Two isoforms of APX differing in their mobility (Rf 0.89 and Rf 0.96) and one isoform of catalase from barley seedlings were observed in electrophoretic spectra. Anological results were also obtained by other authors [36] [37].

Thus, the obtained results suggest that drought tolerance of barley is closely related to the antioxidant protection system. Biochemical study of some oxidative enzymes and their multiple isoenzymes allows us to assess their enzymatic activities in barley plants and to coordinate this parameter with physiological and

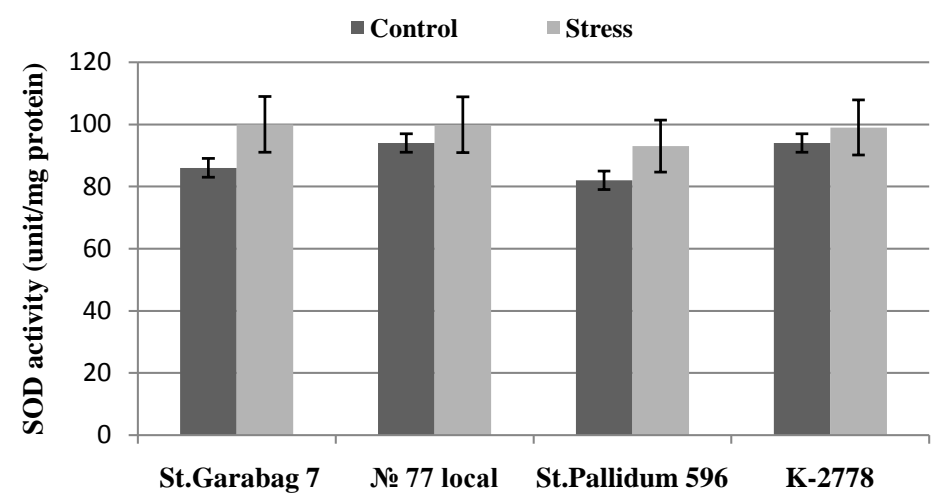

Figure 4. SOD activity of barley leaves under soil water shortage.

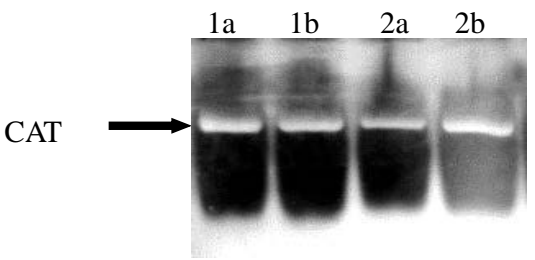

Figure 5. Isoenzyme pattern of CAT in the leaves of K-2778 (1) and St.Pallidum 596 (2) barley genotypes: a-normal irrigation, b-drought. 


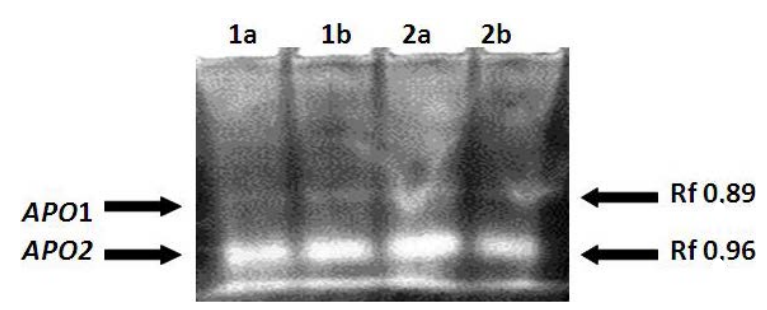

Figure 6. Isoenzyme patterns of APX in the leaves of K-2778 (1) and 2-St.Pallidum 596 (2) barley genotypes: a-normal irrigation, b-drought.

morphological processes. Barley plants maintain their life functions and homeostasis under extremal conditions due to qualitative and quantitative changes in activities and isoenzyme contents of antioxidant enzymes. The obtained data can play a role of theoretical basis for creation of new test systems to assess drought tolerance.

\section{References}

[1] Aranjuelo, I., Molero, G., Erice, G., Avice, J.C. and Nogués, S. (2011) Plant Physiology and Proteomics Reveals the Leaf Response to Drought in Alfalfa (Medicago sativa L.). Journal of Experimental Botany, 62, 111-123. http://dx.doi.org/10.1093/jxb/erq249

[2] Li, Z., Shi, P. and Peng, Y. (2013) Improved Drought Tolerance through Drought Preconditioning Associated with Changes in Antioxidant Enzyme Activities, Gene Expression and Osmoregulatory Solutes Accumulation in White Clover (Trifolium repens L.). Plant Omics, 6, 481-489.

[3] Solomon, S., Qin, D., Manning, M., Alley, R.B., Berntsen, T., Bindoff, N.L., Chen, Z., Chidthaisong, A., Gregory, J.M., Hegerl, G.C., Heimann, M., Hewitson, B., Hoskins, B.J., Joos, F., Jouzel, J., Kattsov, V., Lohmann, U., Matsuno, T., Molina, M., Nicholls, N., Overpeck, J., Raga, G., Ramaswamy, V., Ren, J., Rusticucci, M., Somerville, R., Stocker, T.F., Whetton, P., Wood, R.A. and Wratt, D. (2007) Technical Summary. In: Solomon, S., Qin, D., Manning, M., Chen, Z., Marquis, M., Averyt, K.B., Tignor, M. and Miller, H.L. Eds., Climate Change 2007: The Physical Science Basis, Contribution of Working Group I to the Fourth Assessment Report of the Intergovernmental Panel on Climate Change, Cambridge University Press, Cambridge, United Kingdom and New York, USA, 996 p.

[4] Faize, M., Burgos, L., Faize, L., Piqueras, A., Nicolas, E., Barba-Espin, G., Clemente-Moreno, M.J., Alcobendas, R., Artlip, T. and Hernandez, J.A. (2011) Involvement of Cytosolic Ascorbate Peroxidase and Cu/Zn-Superoxide Dismutase for Improved Tolerance against Drought Stress. Journal of Experimental Botany, 62, 2599-2613. http://dx.doi.org/10.1093/jxb/erq432

[5] Apel, K. and Hirt, H. (2004) Reactive Oxygen Species: Metabolism, Oxidative Stress, and Signal Transduction. Annual Review of Plant Biology, 55, 373-399. http://dx.doi.org/10.1146/annurev.arplant.55.031903.141701

[6] Joseph, B. and Jini, D. (2011) Development of Salt Stress-Tolerant Plants by Gene Manipulation of Antioxidant Enzymes. Asian Journal of Agricultural Research, 5, 17-27.

[7] Mittler, R. (2002) Oxidative Stress, Antioxidants and Stress Tolerance. Trends in Plant Science, 7, 405-410. http://dx.doi.org/10.1016/S1360-1385(02)02312-9

[8] Ahmad, P., Jaleel, C.A., Salem, M.A., Nabi, G. and Sharma, S. (2010) Roles of Enzymatic and Nonenzymatic Antioxidants in Plants during Abiotic Stress. Critical Reviews in Biotechnology, 30, 161-175. http://dx.doi.org/10.3109/07388550903524243

[9] Mittler, R., Vanderauwera, S., Gollery, M. and Van Breusegem, F. (2004) Reactive Oxygen Gene Network of Plants. Trends in Plant Science, 9, 1360-1385. http://dx.doi.org/10.1016/j.tplants.2004.08.009

[10] Sarowar, S., Kim, E.N., Kim, Y.J., Ok, S.H., Kim, K.D., Hwang, B.K. and Shin, J.S. (2005) Overexpression of a Pepper Ascorbate Peroxidase-Like 1 Gene in Tobacco Plants Enhances Tolerance to Oxidative Stress and Pathogens. Plant Science, 169, 55-63. http://dx.doi.org/10.1016/j.plantsci.2005.02.025

[11] Shaaltiel, Y., Chua, N.H., Gepstein, S. and Gressel, J. (1988) Dominant Pleiotropy Controls Enzymes Co-Segregating with Paraquet Resistance in Conyza bonariensis. Theoretical and Applied Genetics, 75, 850-856.

[12] Amini, R. (2013) Drought Stress Tolerance of Barley (Hordeum vulgare L.) Affected by Priming with PEG. International Journal of Farming and Allied Sciences, 2, 803-808.

[13] Fayez, K.A. and Bazaid, S.A. (2014) Improving Drought and Salinity Tolerance in Barley by Application of Salicylic Acid and Potassium Nitrate. Journal of the Saudi Society of Agricultural Sciences, 13, 45-55. http://dx.doi.org/10.1016/j.jssas.2013.01.001 
[14] Ashraf, M. (2010) Inducing Drought Tolerance in Plants: Recent Advances. Biotechnology Advances, 28, 169-183. http://dx.doi.org/10.1016/j.biotechadv.2009.11.005

[15] Zhang, J. and Kirkham, M.B. (1994) Drought-Stress-Induced Changes in Activities of Superoxide Dismutase, Catalase and Peroxidase in Wheat Species. Plant and Cell Physiology, 35, 785-791.

[16] Fu, J. and Huang, B. (2001) Involvement of Antioxidants and Lipid Peroxidation in the Adaptation of Two Cool-Season Grasses to Localized Drought Stress. Environmental and Experimental Botany, 45, 105-114. http://dx.doi.org/10.1016/S0098-8472(00)00084-8

[17] Shao, H.B., Liang, Z.S., Shao, M.A. and Su, Q. (2005) Dynamic Changes of Antioxidative Enzymes of 10 Wheat Genotypes at Soil Water Deficits. Colloids and Surfaces B: Biointerfaces, 42, 187-195. http://dx.doi.org/10.1016/j.colsurfb.2005.02.007

[18] Polesskaya, O.G. (2007) Plant Cell and Reactive Oxygen Species. Yermakov, I.P., Ed., Moscow, 140.

[19] Kumar, C.N. and Knowles, N. (1993) Changes in Lipid Peroxidation and Lipolytic and Free-Radical Scavenging Enzyme during Aging and Sprouting of Potato (Solanum tuberosum L.) Seed-Tubers. Plant Physiology, 102, 115-124. http://dx.doi.org/10.1104/pp.102.1.115

[20] Nakano, Y. and Asada, K. (1981) Hydrogen Peroxide Is Scavenged by Ascorbate-Specific Peroxidase in Spinach Chloroplasts. Plant and Cell Physiology, 22, 867-880.

[21] Yannarelli, G.G., Fernández-Alvarez, A.J., Santa-Cruz, D.M. and Tomaro, M.L. (2007) Glutathione Reductase Activity and Isoforms in Leaves and Roots of Wheat Plants Subjected to Cadmium Stress. Phytochemistry, 68, 505-512. http://dx.doi.org/10.1016/j.phytochem.2006.11.016

[22] Sedmak, J.J. and Grossberg, S.E. (1977) A Rapid, Sensitive, and Versatile Assay for Protein Using Coomassie Brilliant Blue G250. Analytical Biochemistry, 79, 544-552. http://dx.doi.org/10.1016/0003-2697(77)90428-6

[23] Laemmli, U.K. (1970) Cleavage of Structural Proteins during the Assembly of the Head of Bacteriophage T4. Nature, 227, 680-685. http://dx.doi.org/10.1038/227680a0

[24] Mittler, R, and Zilinskas, B.A. (1993) Detection of Ascorbate Peroxidase Activity in Native Gels by Inhibition of the Ascorbate-Dependent Reduction of Nitroblue Tetrazolium. Analytical Biochemistry, 212, 540-546.

[25] Woodbury, W., Spencer, A.K. and Stahmann, M.A. (1971) An Improved Procedure Using Ferricyanide for Detecting Catalase Isoenzymes. Analytical Biochemistry, 44, 301-305. http://dx.doi.org/10.1016/0003-2697(71)90375-7

[26] Mhamdi, A., Queval, G., Chaouch, S., Vanderauwera, S., Van Breusegem, F. and Noctor, G. (2010) Catalase Function in Plants: A Focus on Arabidopsis Mutants as Stress-Mimic Models. Journal of Experimental Botany, 61, 4197-4220. http://dx.doi.org/10.1093/jxb/erq282

[27] Najami, N., Janda, T., Barriah, W., Kayam, G., Tal, M., Guy, M. and Volokita, M. (2008) Ascorbate Peroxidase Gene Family in Tomato: Its Identification and Characterization. Molecular Genetics and Genomics, 279, 171-182. http://dx.doi.org/10.1007/s00438-007-0305-2

[28] Gill, S.S. and Tuteja, N. (2010) Reactive Oxygen Species and Antioxidant Machinery in Abiotic Stress Tolerance in Crop Plants. Plant Physiology and Biochemistry, 48, 909-930. http://dx.doi.org/10.1016/j.plaphy.2010.08.016

[29] Badiani, M., De Biasi, M.G., Colognola, M. and Artemi, F. (1990) Catalase, Peroxidase and Superoxide Dismutase Activities in Seedlings Submitted to Increasing Water Deficit. Agrochimica, 34, 90-102.

[30] Yoshimura, K., Yabuta, Y., Ishikawa, T. and Shigeoka, S. (2000) Expression of Spinach Ascorbate Peroxidase Isoenzymes in Response to Oxidative Stresses. Plant Physiology, 123, 223-234. http://dx.doi.org/10.1104/pp.123.1.223

[31] Saruhan, N., Terzi, N., Saglam, A. and Kadioglu, A. (2009) The Relationship between Leaf Rolling and AscorbateGlutathione Cycle Enzymes in Apoplastic and Symplastic Areas of Ctenanthe setosa Subjected to Drought Stress. Biological Research, 42, 315-326. http://dx.doi.org/10.4067/S0716-97602009000300006

[32] Romero-Puertas, M.C., Corpas, F.J., Sandalio, L.M., Leterrier, M., Rodriguez-Serrano, M., Del Río, L.A., et al. (2006) Glutathione Reductase from Pea Leaves: Response to Abiotic Stress and Characterization of the Peroxisomal Isozyme. New Phytologist, 170, 43-52.

[33] Alscher, R.G., Donahue, J.L. and Cramer, C.L. (2002) Reactive Oxygen Species and Antioxidants: Relationships in Green Cells. Physiologia Plantarum, 100, 224-233. http://dx.doi.org/10.1111/j.1399-3054.1997.tb04778.x

[34] Raychaudhuri, S.S. and Deng, X.W. (2000) The Role of Superoxide Dismutase in Combating Oxidative Stress in Higher Plants. The Botanical Review, 66, 89-98. http://dx.doi.org/10.1007/BF02857783

[35] Brou, Y.C., Zeze, A., Diouf, O. and Eyletters, M. (2007) Water Stress Induces Overexpression of Superoxide Dismutases That Contribute to the Protection of Cowpea Plants against Oxidative Stress. African J. Biotech., 6, 1982-1986.

[36] Kim, S.Y., Lim, J.H., Park, M.R., Kim, Y.J., Park, T.I., Seo, Y.W., Choi, K.G. and Yun, S.J. (2005) Enhanced Antioxidant Enzymes Are Associated with Reduced Hydrogen Peroxide in Barley Roots under Saline Stress. Journal of Bi- 
ochemistry and Molecular Biology, 38, 218-224. http://dx.doi.org/10.5483/BMBRep.2005.38.2.218

[37] Domanskaya, I.N., Budakova, E.A., Samovich, T.V., Spivak, E.A. and Shaligo, N.V. (2009) Activities of the Antioxidant Enzymes in Green Seedlings of Barley (Hordeum vulgare) under Drought Conditions. Proceedings of the Academy of Sciences of Belarus (Series of Biological Sciences), 4, 45-49. 
Scientific Research Publishing (SCIRP) is one of the largest Open Access journal publishers. It is currently publishing more than 200 open access, online, peer-reviewed journals covering a wide range of academic disciplines. SCIRP serves the worldwide academic communities and contributes to the progress and application of science with its publication.

Other selected journals from SCIRP are listed as below. Submit your manuscript to us via either submit@scirp.org or Online Submission Portal.
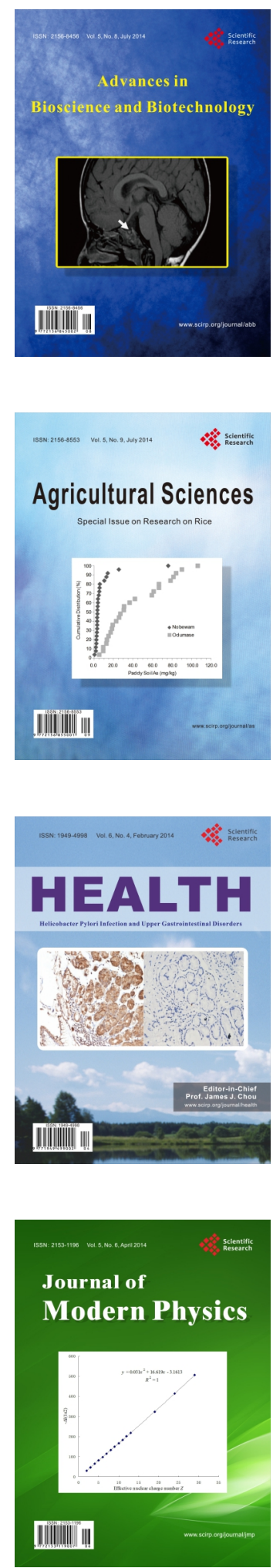
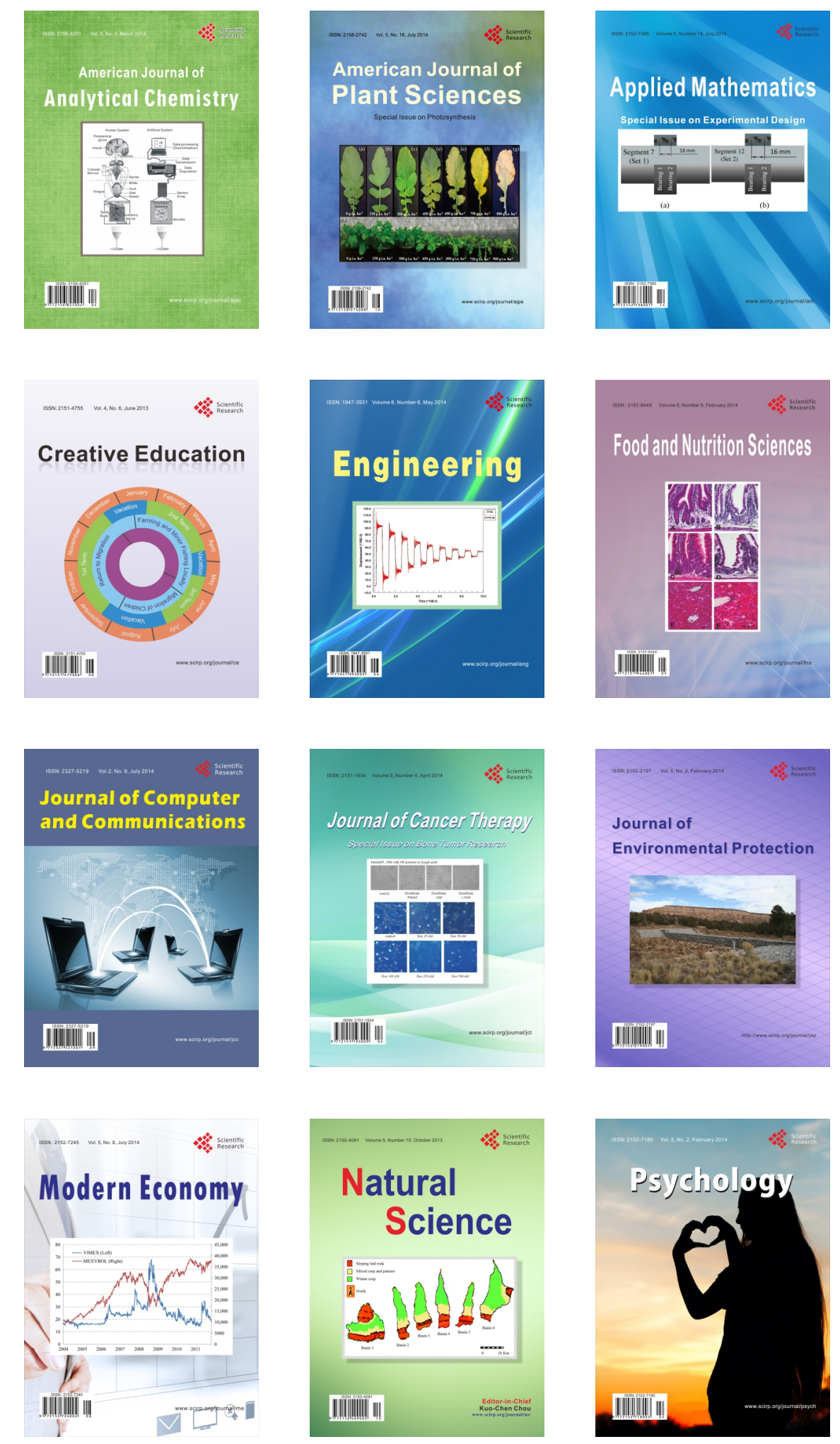